\title{
Cultural values in the study of the society's entrepreneurial potential
}

\author{
InmaculadaJaén \\ Dept.Applied Economics I \\ University of Seville(Spain) \\ Tel.: +34.954557550. Fax: +34.954551636 \\ inmajaen@us.es \\ Francisco Liñán \\ Dept. Applied Economics I \\ University of Seville(Spain) \\ Tel.: +34.954554487. Fax: +34.954551636 \\ flinan@us.es
}

\section{Acknowledgements}

This study it is part of the VIE Project (Cultural Values and Socioeconomic Factors as determinants of the Entrepreneurial Intention), which has been financed by the regional government of Andalusia (Department of Innovation, Science and Enterprise; Reference Number: P08-SEJ-03542).

We are also grateful to the universities collaborating in the data gathering (a complete list of them is published at the project web-page: http://institucional.us.es/vie). 


\title{
Cultural values in the study of the society's entrepreneurial potential
}

\begin{abstract}
This paper attempts to measure the importance of a region's cultural values in determining the entrepreneurial intention of each of its members separately. Schwartz's (2004) approach will be followed in measuring cultural values, together with Ajzen's (1991) theory of planned behaviour with regard to entrepreneurial intentions. The empirical study has been conducted on a sample of 2974 university graduates as part of VIE project. Results show that the region's culture indirectly influences the entrepreneurial intention of its member. People in some regions do feel a more positive attitude, subjective norm or perceived behavioural control due to its cultural characteristics.
\end{abstract}

Keywords: cultural values, entrepreneurial intention, Spanish regions, value structure, cognitive research

\section{Introduction}

There are differences in the levels of entrepreneurial activity between countries and regions. These differences cannot be fully explained by economic variables alone (Davidsson \& Wiklund, 1997; Frederking, 2004). A substantial portion of these differences have been attributed to culture (Davidsson, 1995). Inglehart (1997) defines it as the set of basic common values which contributes to shaping people's behaviour in a society. The notion of culture also includes patterns of thinking, feeling and acting, which are learned and shared by people living within the same social environment (Hofstede, 1991, 2003). However, very little is still known about the kind of influence that each society's culture exerts on the entrepreneurial potential of its members.

Currently, cross-cultural theories (Hofstede, 1980; Inglehart, 1997; Schwartz, 1994; Triandis, 1995) are widely used to compare contemporary societies. Cultural-level values represent socially-shared abstract ideas about what is good and right and desirable in a society (Williams, 1968). These values form the basis of shared norms that prescribe appropriate behaviour in each situation within a society (Schwartz, 1994). Therefore, they are inherent in the structure and functioning of social institutions. Predominant cultural values characterizing a society cannot be observed directly, but must be inferred by studying the values of individuals (Hofstede, 1980; Kahl, 1968; Schwartz \& Ros, 1995). Schwartz (1994) identifies seven types of values (cultural orientations) that allow comparing different cultures: Embeddedness, Intellectual Autonomy, Affective Autonomy, Hierarchy, Egalitarianism, Mastery and Harmony. These seven cultural orientations would be structured around three bipolar dimensions. 
The societal value structure that shapes culture may play a significant role in determining the entrepreneurial intention of their members. This value structure may exert its influence either through social legitimation at the aggregate level (Etzioni, 1987) or by promoting each individual's intention separately (Krueger, 2000, 2003), or both (Davidsson, 1995). It has also been argued that it is misfit individuals who start most ventures in each society (Hofstede, et al., 2004). It is expected that the individuals in a society will be affected by the culture around them when determining their intention to become entrepreneurs.

Thus, this study aims at understanding the relationship between cultural values and the individual's entrepreneurial potential better. To do so, it will analyse the possible effect of regional culture (shared values) on the individual's entrepreneurial intention. In this sense, it is expected that aggregate cultural values interact with the personal valuestructure of each individual, leading to different attitudes and intentions.

To do so, after this introduction, the next section reviews the relevant literature. In section three, the methodology is described. Results are presented in section four. The papers ends with a discussion of these results and a conclusion section.

\section{Theoretical framework}

Entrepreneurship is considered one of the most important factors contributing to economic development and has numerous benefits for the society. It drives innovation, creates jobs, develops human potential, and satisfies new customer demands (European Commission, 2003). However, only a small percentage of the working population typically engages in entrepreneurship (Bosma \& Levie, 2010). Such evidence has compelled researchers to employ socio-cognitive models and theories to identify the antecedents of entrepreneurial intention (Alexei \& Kolvereid, 1999; Audet, 2004; Autio, Keeley, Klofsten, Parker \& Hay, 2001; Li, 2006; Liñán \& Chen, 2009; Moriano, Palací \& Morales, 2007; Pihie, 2009).

An important policy question has been raised regarding this subject: How to improve people's inclination toward developing new entrepreneurial initiatives (OECD, 1998). The European Union has attempted to achieve this objective through short-term policies focused on eliminating barriers to the development and growth of businesses. However, the concession of grants and the removal of red tape have not had the expected impact on the creation of new businesses. This has led to the adoption of a new approach whose principal objective is to ensure that more people decide to become entrepreneurs and work towards that end (European Commission, 2003).

Methodologies used so far to study the entrepreneurial decision have been changing along the years. After personality traits (Kets de Vries, 1977; McClelland, 1961) or demographic variables (Reynolds, Storey \& Westhead, 1994; Storey, 1994), researchers have stressed the importance of cognitive factors. Thus, since the mid-1990s, this line of research has been very fruitful in studying entrepreneurship (Baron, 1998; Baron, 2004; Baum, Frese \& Baron, 2007; Busenitz \& Lau, 1996; Krueger, 2000; Neck, Neck, Manz \& Godwin, 1999). 
The creation of a new company requires time, involving both considerable planning and a high degree of cognitive processing. Therefore, the entrepreneurial behaviour could be considered as a type of planned behaviour for which the intention models are ideally convenient (Krueger \& Carsrud, 1993; Krueger, Reilly \& Carsrud, 2000). In this sense, the entrepreneurial intention would be a previous and determinant element towards performing entrepreneurial behaviours (Bird, 1988; Kolvereid, 1996). Several models have been used to explain the entrepreneurial intention such as Shapero's (1982) Entrepreneurial Event Model, the Model of Implementing Entrepreneurial Ideas (Bird, 1988) or Maximization of the Expected Utility (Douglas \& Shepherd, 2000). Although these different models represent a step forward in entrepreneurial-behaviour research, they have not been as influential as the Theory of Planned Behaviour (TPB, Autio, et al., 2001; Krueger \& Carsrud, 1993; Krueger, et al., 2000; Liñán \& Chen, 2009; Tkachev \& Kolvereid, 1999; van Gelderen, et al., 2006). Unlike other models, the TPB offers a coherent and generally applicable theoretical framework, which enables us to understand and predict entrepreneurial intention by taking into account not only personal but also social factors (Krueger et al., 2000).

Three elements explain intention, according to the TPB. Firstly, the attitude towards behaviour within the TPB is defined as an individual's overall evaluation of the behaviour (Ajzen, 1991). It is determined by the total set of accessible behavioural beliefs linking the behaviour to various outcomes and other attributes. In addition, the strength of each belief is weighted by the evaluation of the outcomes (Ajzen, 1991). The second component of the TPB is the subjective norm, which is defined as the individual's perception of the social pressures to engage (or not to engage) in entrepreneurial behaviour (Ajzen, 1991). The subjective norm consists of two components: normative beliefs and the motivation to comply with these beliefs (Ajzen \& Fishbein, 1980). The third TPB component, perceived behavioural control (PBC), refers to people's perceptions of their ability to perform that behaviour. This concept is, therefore, very similar to self-efficacy (or even the same, see Bandura, 1982). In fact, self-efficacy has replaced PBC in numerous studies (Krueger et al., 2000; Kolvereid \&Isaksen, 2006; Moriano, 2005; van Gelderen et al., 2008), and a recent meta-analysis showed that it is strongly positively related to business creation and entrepreneurial success (Rauch \& Frese, 2007).

Among the explaining variables in the TPB model (Ajzen, 1991, 2001, 2005), subjective norm reflects the influence of the closer social environment. That is, the belief that important referent people will approve or reject the start-up behaviour (normative belief), together with the willingness to conform to these norms (motivation to comply). Nevertheless, they refer to the small group of people that is in direct contact with the individual. Additionally, it is expected that the overall social or cultural beliefs will also have some effect on the personal decision.

Both personal and cultural values are likely to influence behaviour, as shown in the social-psychology literature (Verplanken \& Holland, 2002). The study of values can be done from an individual perspective (i.e., at the individual level) or a cultural perspective (from the society's level of analysis). However, both dimensions (personal and cultural values) are related. Still, we must bear in mind that there is a conceptual difference between both levels (Schwartz, 1994, 2007). Personal values represent the individual goals and motivations who serve as a guiding principle in live (Rokeach, 1973; Schwartz \& Bilsky, 1987, 1990). In contrast, values at the cultural level represent abstract ideas, socially shared, about what is good and right and desirable in a society 
(Williams, 1968). Cultural values are inherent to the structure and functioning of social institutions (Schwartz \& Ros, 1995).

At the personal level, Feather (1995) argues that people's values induce valences on possible actions. That is, actions become more attractive, more valued subjectively, to the extent that they promote attainment of valued goals. People who value stimulation would likely be attracted to a challenging job offer whereas those who value security might find the same offer threatening and unattractive (Schwartz, 2006). Thus, an opportunity to attain one of these highly prioritized values will set off an automatic, positive, affective response to actions that will serve them. On the contrary, if a threat to value attainment is sensed, a negative affective response will set off.

Even in more complex decisions involving the need to develop careful plans, values play a relevant role. More important goals induce a stronger motivation to plan thoroughly. The higher the priority given to a value, the more likely people will form action plans that can lead to its expression in behaviour (Gollwitzer, 1996). Planning focuses people on the pros of desired actions rather than the cons. It enhances their belief in their ability to reach the valued goal and increases persistence in the face of obstacles and distractions. By promoting planning, value importance increases valueconsistent behaviour (Schwartz, 2006).

Starting from personal-level values, researchers have moved their focus to consider the study of one culture or even cross-cultural comparative studies (Fischer, 2004). The most important classical theories developed to address the concept and structure of cultural values are those of Hofstede (1980, 1991, 2003), Schwartz (1994, 1999), Triandis (1995) and Inglehart (1990, 1997). While they differ in both their methodology and approach, they all share the same goal; determine a comparative framework that serves to make comparisons between cultures.

In this paper, Schwartz's theory will be considered, which considers cultural values as averaged individual values (Schwartz, 1992, 1994, 1999, 2004). It establishes a universal system of values that guide human behaviour. Specific cultural contexts make some of them prevailing over the others (Schwartz, 1992). This mechanism works through social institutions and their actions (through legislation, government directives, the education system, etc.), selecting and prioritizing some values over the others. In this sense, people tend to carry out what they believe is socially appropriate behaviour (Bourdieu, 1991; Markus \& Kitayama, 1991; Schwartz, 1994).

At the aggregate level, seven types of cultural values may be identified (Schwartz, 1994): Embeddedness, Intellectual Autonomy, Affective Autonomy, Hierarchy, Egalitarianism, Mastery and Harmony. They may be grouped into three bipolar dimensions (See Figure 1).

- Embeddedness vs. Autonomy (intellectual and emotional): This dimension covers the troubled relationship between the individual and the group. At the Embeddedness end, the person is seen as an entity that is included in the community (examples of values may be social order, respect for tradition, family security or wisdom). Meanwhile, at the other end, the person is an autonomous body that finds meaning in his own difference (to be curious, open-minded, creative are values within the Intellectual Autonomy; pleasure, varied life, exciting life are Affective Autonomy values). Of course, the relative strength of Affective and Intellectual autonomies may 
make a difference at the cultural level (see Schwartz \& Ros, 1995 for a comparison of western European countries).

This dimension partly overlaps with Hofstede's (1980, 2003) individualismcollectivism. However, embeddedness-autonomy contrasts openness to change with maintaining the status quo, whereas individualism-collectivism does not. Many theorists associate individualism with the self-interested pursuit of personal goals (Kagitcibasi, 1997; Triandis, 1995). However, self-interest is equally present in both sides of the embeddedness-autonomy dimension (Schwartz, 2004).

It also shares some elements with Inglehart's (1997) tradition/secular-rational dimension, since they both concern the degree to which the individual is submerged in all-encompassing structures of tight mutual obligations. In traditional societies, peoples' ties to their religious, national, and family groups are the source of meaning in their lives (Inglehart \& Baker, 2000) - a core aspect of embeddedness. The weakening of encompassing structures and of absolute standards in secular-rational societies frees individuals to think, do, and feel more independently - a core aspect of autonomy. Similarly, Inglehart's second dimension (survival/self-expression) also overlaps with the embeddedness-autonomy dimension. They both concern the degree to which individuals should be encouraged to express their uniqueness and independence in thought, action, and feelings.

- Hierarchy vs. Egalitarianism: The second societal problem is to guarantee responsible behaviour that preserves the social fabric. People must be induced to consider the welfare of others, to coordinate with them, and thereby manage their unavoidable interdependencies. At the Hierarchy end of this dimension, the unequal distribution of power, roles and resources (social values such as power, authority, humility, wealth) is considered legitimate. Meanwhile, at the Egalitarianism end, the members of society are considered as equal beings who share a commitment to cooperate with others and pursue the common good (social values like justice, freedom, responsibility, honesty).

The hierarchy pole of the egalitarianism-hierarchy dimension has some conceptual overlap with Hofstede's (1980) power distance. Both concern legitimizing social inequality. However, power distance refers to the acceptance of inequality by less powerful people and expresses their fear of authority. In contrast, the egalitarianhierarchy dimension addresses the responsible, cooperative behaviour that will get societal tasks done, either by differentiating roles or by internalizing commitment and voluntary cooperation.

There is also some overlap with Inglehart's (1997) survival/self-expression, since it relates to trust, tolerance and support for the equal rights of out-groups. These elements are present in egalitarianism.

- Mastery vs. Harmony: This dimension helps solving the problems of the relations between person and nature. Those cultures heavily sided towards the Mastery pole are seeking personal gain through the exploitation and domination of nature (ambitious, successful, competitive, risk-taker). In the Harmony side, instead, cultures that seek individuals fitting harmoniously with nature (unity with nature, protecting the environment ...) are placed. 
The mastery pole has some conceptual overlap with Hofstede's (1980) masculinity. Both emphasize assertiveness and ambition. However, masculinity is opposed to femininity (tenderness, care, and concern for others), thus neglecting the interests of others. In contrast, mastery is opposed to harmony (being in tune with others and the environment), but it does not imply selfishness.

Similarly, harmony might seem to overlap conceptually with uncertainty avoidance, since both idealize a harmonious order. However, harmony stresses that people and nature should exist comfortably together without assertion of control. In contrast, uncertainty avoidance emphasizes controlling ambiguity and unpredictability through institutions and beliefs that provide certainty.

Figure 1. Cultural value dimensions

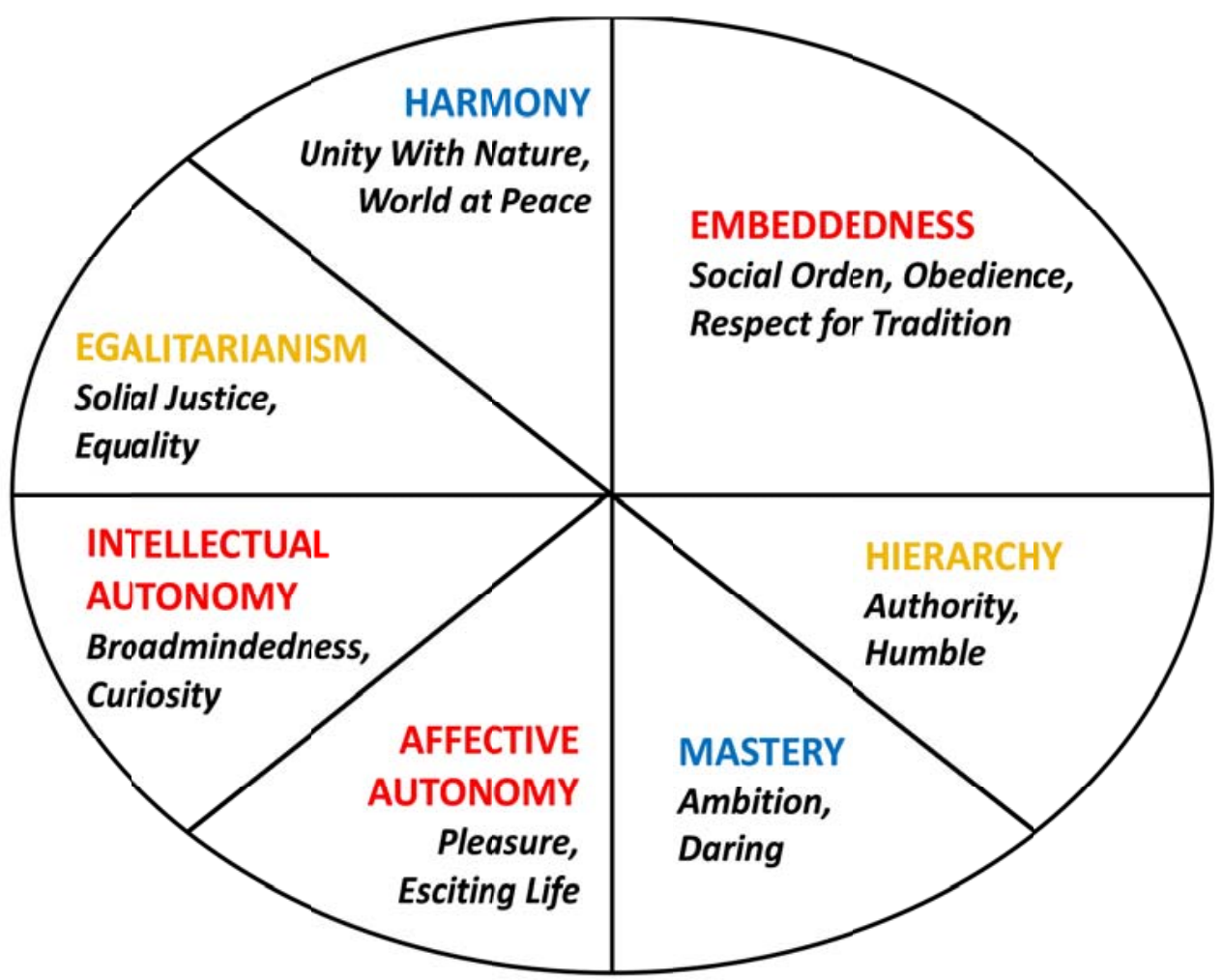

Source: Schwartz (2004), Figure 1.

These cultural value orientations also present a framework of cultural compatibility (Schwartz, 1994), since some of them share some basic assumptions. For instance, hierarchy and embeddedness are positively related, sharing the idea that personal roles and obligations to collectivities are more important than individual ideas and aspirations. The same is true about egalitarianism and intellectual autonomy. They share the idea of a social actor who takes individual responsibility and make personal decisions based on their understanding of situations. In practice, high egalitarianism and intellectual autonomy are usually found together, as in Western Europe (Schwartz \& Ros, 1995). 
The shared and opposing assumptions inherent in cultural values yield a coherent circular structure of relations among them (Schwartz, 1999). The structure reflects the cultural orientations that are compatible (adjacent in the circle) or incompatible (distant around the circle). This conception of cultural dimensions as forming an integrated system, derived from a priori theorizing, distinguishes this approach from others. Hofstede $(1980,2001)$ conceptualized his dimensions as independent, while Inglehart (1997) derived his two broad cultural components empirically.

Since the TPB model establishes that intention is explained by its three antecedents alone (Ajzen, 1991), it is expected that the influence of cultural values on entrepreneurial intention should be indirect, through its effect on intention antecedents. Therefore, based on this theory, the present study aims at testing the following hypotheses:

H1: Predominant cultural values in the region do not have a direct effect on the entrepreneurial intention of its people.

H2: Predominant cultural values in the region have an indirect effect on the entrepreneurial intention of its people through its antecedents (attitude to entrepreneurship, subjective norm and perceived behavioural control).

\section{Methodology}

The empirical study has been conducted on a sample of university graduates obtained as part of VIE project (Values and Entrepreneurial Intentions) in which a questionnaire was developed to study the values, motivations and intentions of potential entrepreneurs. 3223 Spanish university graduates participated in the study (mean age 28.08; $S D=4.98$ ) from 15 different universities in Spain ${ }^{1}$. Table 1 shows some of the main sample characteristics. The vast majority of responses (2974, 92.3\% of the total sample) corresponded to seven of the 17 regions in which Spain is divided. Therefore, these seven regions are to be studied, and the remaining cases disregarded (see Table 2).

Participation in the study was voluntary. All questionnaires were completed anonymously to ensure confidentiality. Questionnaires were completed over the Internet, as part of the development of the VIE Project. The VIE project attempts to assess the influence of personal and cultural values, together with socioeconomic variables, in the formation of entrepreneurial attitudes and intentions. All 74 universities in Spain have been contacted, asking them to distribute the information about the project and the questionnaire to their alumni. Collaboration was obtained from 15 of them. Data collection stretched from February to October 2010.

\footnotetext{
${ }^{1}$ The complete list of collaborating universities is included in the Project web-page: http://institucional.us.es/vie
} 


\section{Measurement Instrument}

The VIE questionnaire includes a TPB questionnaire and Schwartz's PVQ (Portrait Value Questionnaire). The former measures entrepreneurial intention and its antecedents, whereas the latter measures value priorities. The TPB questionnaire comprises four subscales: attitude towards entrepreneurship, subjective norms, PBC, and entrepreneurial intention. Unlike other questionnaires used in the field (Autio et al., 2001; Krueger et al., 2000; Liñán \& Chen, 2009), EIQ follows Ajzen’s (2002a) methodological recommendations of how to construct a TPB questionnaire using composite measures of attitudes and subjective norms. All items in the questionnaire were measured on a 7-point Likert Scale (from 0 to 6). The EIQ instrument is available from the authors upon request.

Table 1. Sample characteristics

\begin{tabular}{|c|c|c|c|c|c|c|c|}
\hline & Mean & $\begin{array}{l}\text { Std. } \\
\text { dev. }\end{array}$ & $\begin{array}{c}\mathbf{0} \\
(\%)\end{array}$ & $\begin{array}{c}1 \\
(\%)\end{array}$ & $\begin{array}{c}2 \\
(\%)\end{array}$ & $\begin{array}{c}3 \\
(\%) \\
\end{array}$ & $\begin{array}{c}4 \\
(\%) \\
\end{array}$ \\
\hline \multirow[t]{2}{*}{ Age } & 28.08 & 4.96 & & & & & \\
\hline & & & Female & Male & & & \\
\hline \multirow[t]{2}{*}{ Gender } & 0.43 & 0.48 & 57.5 & 42.5 & & & \\
\hline & & & No & Yes & & & \\
\hline Labour experience & 0.90 & 0.30 & 9.8 & 90.2 & & & \\
\hline $\begin{array}{l}\text { Self-employment } \\
\text { experience }\end{array}$ & 0.13 & 0.34 & 86.6 & 13.4 & & & \\
\hline Family role model & 0.62 & 0.49 & 37.9 & 62.1 & & & \\
\hline $\begin{array}{l}\text { Contact with } \\
\text { entrepreneurship centre }\end{array}$ & 0.19 & 0.39 & 80.8 & 19.2 & & & \\
\hline & & & Lower & $\begin{array}{l}\text { Lower- } \\
\text { middle }\end{array}$ & Middle & $\begin{array}{l}\text { Upper- } \\
\text { middle }\end{array}$ & Upper \\
\hline Socioeconomic level & 1.89 & 0.65 & 2.6 & 19.1 & 65.1 & 13.1 & 0.2 \\
\hline & & & $\begin{array}{l}\text { Priv. sect. } \\
\text { employee }\end{array}$ & $\begin{array}{l}\text { Pub. sect. } \\
\text { employee }\end{array}$ & \begin{tabular}{|c|}
$\begin{array}{c}\text { Self- } \\
\text { employed }\end{array}$ \\
\end{tabular} & $\begin{array}{c}\text { Un- } \\
\text { employed }\end{array}$ & Other \\
\hline Occupational status & -- & -- & 40.8 & 16.3 & 7.1 & 28.2 & 7.5 \\
\hline
\end{tabular}

The dependent variable, entrepreneurial intention, was measured using a five-item scale in which each item assesses the perceived likelihood of an individual to choose an entrepreneurial career. Higher scores reflect stronger entrepreneurial intentions.

The independent variables include TPB antecedents. Attitude towards entrepreneurship was measured through two sets of six items that assess expected outcomes of an entrepreneurial career as well as desirability of these outcomes. Following Ajzen (2002a), outcome expectations were multiplied by their desirability and then divided by six to obtain scale average scores. Subjective norms were measured with two sets consisting of three items each measuring how significant others (e.g. parents) would view their entrepreneurial career choice as well as their motivation to comply with these reference people. These two sets were multiplied and then divided by three. Perceived behavioural control has been measured through a six-item scale, combining elements of self-efficacy and controllability, in line with the theory (Ajzen, 1991, 2002b) and other research on entrepreneurial intentions (Krueger et al., 2000; 
Kolvereid \& Isaksen, 2006; Moriano, 2005; van Gelderen (van Gelderen, et al., 2008). In all cases, higher scores indicate a higher (more positive) level of the variable.

Values have been measured through Schwartz's (2006) PVQ. It includes 40 statements describing different profiles of people. Respondents are asked to state the extent to which they identify themselves with these profiles. The average for each region has been computed for the 40 value-items. These regional-level scores were them averaged into seven cultural values following Schwartz (2004) and Ros and Schwartz $(1995)^{2}$. Finally, the seven cultural values were grouped again into three bipolar cultural dimensions, by subtracting the score in the first cultural value from the score in the second: Embeddedness-Autonomy (Autonomy being the average of intellectual and affective autonomy), Hierarchy-Egalitarianism and Mastery-Harmony. In all three cases, a negative value represent predominance of the first element (Embeddedness, hierarchy or mastery), whereas a positive value reflects the predominance of the second element (autonomy, egalitarianism or harmony). Table 2 presents the average scores for each of the seven regions studied.

Table 2. Cultural dimensions and Income in the Spanish regions

\begin{tabular}{lccccc}
\multicolumn{1}{c}{ Region } & $\mathbf{N}$ & $\begin{array}{c}\text { Embeddedness } \\
\text { vs. Autonomy }\end{array}$ & $\begin{array}{c}\text { Hierarchy vs. } \\
\text { Egalitarianism }\end{array}$ & $\begin{array}{c}\text { Mastery vs. } \\
\text { Harmony }\end{array}$ & $\begin{array}{c}\text { GDP per } \\
\text { capita }\end{array}$ \\
\hline Andalusia & 815 & .886 & 1.627 & .260 & $75.5 \%$ \\
Castilla-Leon & 492 & .845 & 1.642 & .290 & $99.6 \%$ \\
Catalonia & 176 & $\mathbf{1 . 0 0 7}$ & 1.665 & .283 & $\mathbf{1 1 7 . 3 \%}$ \\
Valencia & 649 & $\mathbf{. 9 8 3}$ & 1.534 & .276 & $88.7 \%$ \\
Galicia & 251 & .767 & $\mathbf{1 . 9 8 6}$ & .536 & $88.2 \%$ \\
Madrid & 340 & $\mathbf{1 . 0 2 5}$ & $\mathbf{1 . 7 3 4}$ & .294 & $\mathbf{1 2 9 . 9 \%}$ \\
Basque Country & 251 & .736 & $\mathbf{1 . 8 0 9}$ & $\mathbf{. 6 5 4}$ & $\mathbf{1 3 5 . 8 \%}$ \\
\hline Total & $\mathbf{2 9 7 4}$ & $\mathbf{. 9 0 1}$ & $\mathbf{1 . 6 6 9}$ & $\mathbf{. 3 3 0}$ & $\mathbf{1 0 0 . 0 \%}$ \\
\hline
\end{tabular}

Note: Above-average figures are highlighted.

As may be seen from Table 2, there are noticeable cultural differences between the seven Spanish regions, despite belonging to the same country. All of them, however, tend to stress autonomy over embeddedness, egalitarianism over hierarchy and, to a lower extent, harmony over mastery, as would be expected of a western European country (Schwartz, 2004; Schwartz \& Ros, 1995). Two culturally differentiated regions emerge, though (See Figure 2). The Mediterranean (Catalonia and Valencia) exhibits below average egalitarianism and harmony, while above average autonomy. In contrast, the north (Basque country and Galicia) is relatively high on the former two dimensions, while lower on autonomy. Castilla-Leon is a relatively northern in-land region, but is culturally very similar to Andalusia on these three dimensions (although their income level and many other social conditions differs widely). Finally, Madrid is also in-land, but it is culturally closer to Catalonia in autonomy (above average) and harmony (below average), but higher than this region in egalitarianism. The Basque country is also

\footnotetext{
${ }^{2}$ An Exploratory Factor Analysis was carried out to confirm that the items theoretically included in each cultural value were empirically supported by the data. Only 4 items were clearly placed in a different value (V9, V15, V34 and V38). However, since they also loaded secondarily on the expected factor, the theoretical distribution was followed.
} 
highly developed, but is clearly different from the other two high-income regions in the sample.

\section{Figure 2. Culturally diverse regions in Spain}

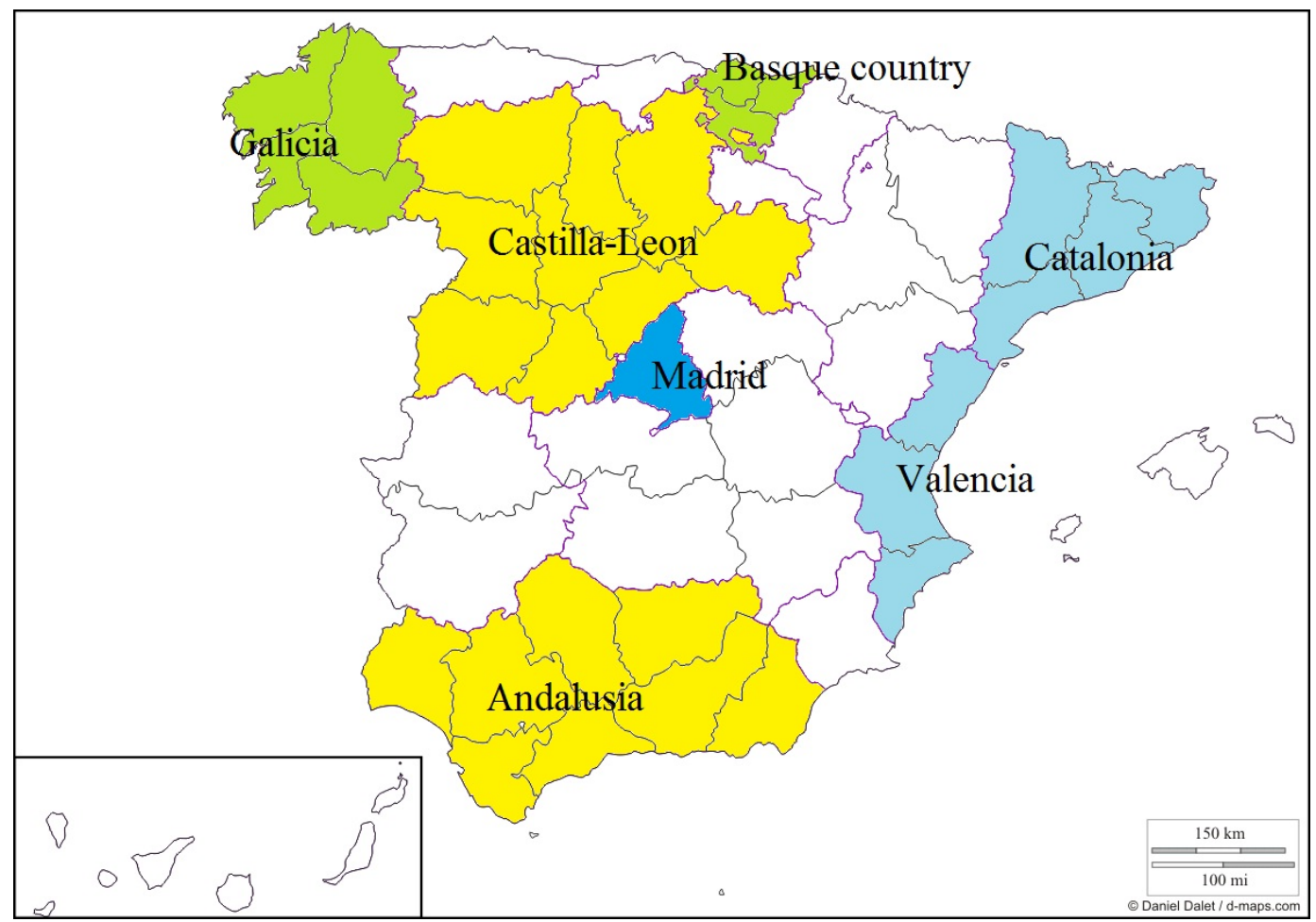

\section{Control variables}

Demographic and socioeconomic characteristics of individuals have been found to correlate with start-up behaviour. Nevertheless, the explaining capacity of these variables have been very limited (Robinson, Stimpson, Huefner \& Hunt, 1991). In this sense, age and gender are typical examples of demographic variables affecting entrepreneurship (Langowitz \& Minniti, 2007; Levesque \& Minniti, 2006). Similarly, People's age, gender, education, and other characteristics largely determine the life circumstances to which they are exposed. These include their socialization and learning experiences, the social roles they play, the expectations and sanctions they encounter, and the abilities they develop. Thus, differences in background characteristics represent differences in the life circumstances that affect value priorities (Schwartz, 2006).

Labour experience and, in particular, self-employment experience are very relevant sources of information, skill-development, and knowledge that may be relevant in the start-up decision (Cooper, Gimeno \& Woo, 1994; Dahlqvist, Davidsson \& Wiklund, 2000). Vicarious learning (Bandura, 1997) may also be important when an entrepreneurial role model is available (Matthews \& Moser, 1996; Scherer, Brodzinsky \& Wiebe, 1991). Therefore, a number of control variables have been considered in the analysis: age, gender, labour experience, self-employment experience, family role model and socioeconomic level. 
Additionally, the development level of each region may affect cultural dimensions and also exert an influence on the entrepreneurial activity of its members. A number of works have found a relationship between economic development and entrepreneurship (Carree, van Stel, Thurik \& Wennekers, 2002; Reynolds, et al., 1994; Van Stel, Wennekers, Thurik \& Reynolds, 2003; Verheul, Wennekers, Audretsch \& Thurik, 2002). In particular, GDP per capita is commonly used to account for economic development in both entrepreneurship (Lee \& Peterson, 2000; Minniti, Bygrave \& Autio, 2006) and cultural (Hofstede, 2003; Hofstede, et al., 2004; Schwartz, 1999, 2004) studies. In this study, the relative level of GDPpc, compared to the national average, has been taken as a proxy for the regional level of economic development (see Table 2).

\section{Results}

Table 3 presents the results of the hierarchical linear regression models with entrepreneurial intention as the dependent variable. Model 1 considers only demographic variables. Initially, age, age-squared and socioeconomic level were included, but strong multicollinearity was present, therefore, they were eliminated. Not surprisingly, males exhibit higher entrepreneurial intentions than females (Minniti \& Nardone, 2007). Similarly, those with previous self-employment experience or a family role model tend to show higher intentions.

Table 3: Linear regression models on entrepreneurial intention

\begin{tabular}{|c|c|c|c|c|}
\hline Variables & $\begin{array}{c}\text { Model } 1 \\
\beta\end{array}$ & $\begin{array}{c}\text { Model } 2 \\
\beta\end{array}$ & $\begin{array}{c}\text { Model } 3 \\
\beta \\
\end{array}$ & $\begin{array}{c}\text { Model } 4 \\
\beta\end{array}$ \\
\hline Gender & $.161 * * *$ & $.116^{* * *}$ & $.110 * * *$ & $.157 * * *$ \\
\hline Labour Experience & .014 & -.008 & .001 & .019 \\
\hline Self-Employment Exp. & $.214^{* * *}$ & $.150 * * *$ & $.153 * * *$ & $.213^{* * *}$ \\
\hline Family Role Model & $.086^{* * *}$ & $.040 * *$ & $.029 *$ & $.076^{* * *}$ \\
\hline Attitude to Entrepreneurship & --- & $.206^{* * *}$ & $.203 * * *$ & --- \\
\hline Subjective norm & --- & $.136 * * *$ & $.135^{* * *}$ & --- \\
\hline $\mathrm{PBC}$ & --- & $.357 * * *$ & $.361^{* * *}$ & --- \\
\hline Embeddedness/Autonomy (centred) & --- & --- & .018 & $.089 * *$ \\
\hline Hierarchy/Egalitarianism (centred) & --- & --- & -.005 & .011 \\
\hline Mastery/Harmony (centred) & --- & --- & -.049 & .036 \\
\hline GDP per capita (centred) & --- & --- & $-.036 t$ & $-.105 * * *$ \\
\hline$R^{2}$ & .087 & .399 & .406 & .097 \\
\hline Adjusted $R^{2}$ & .086 & .397 & .404 & .095 \\
\hline$\Delta R^{2}$ & $.087 * * *$ & $.311 * * *$ & $.007 * * *$ & $.010 * * * a$ \\
\hline
\end{tabular}

${ }^{a}: \Delta R^{2}$ calculated with respect to Model 1 .

$+p<0.1, * p<0.05, * * p<0.01, * * * p<0.001$. 
As a second step (Model 2 in Table 3), the TPB antecedents were included. All three significantly contribute to explaining entrepreneurial intentions, with the expected signs. Besides, as may be observed, they channel part of the effect of the demographic variables (their $\beta$ coefficients are lower than in Model 1).

In Model 3, the regional-level variables (three cultural dimensions and GDP per capita) were included in the analysis. Again, multicollinearity was present. To solve this problem, following practice (Pinillos \& Reyes, 2011; Venkatraman, 1989), the variables were centred (change of origin, with zero mean). Model 3 in Table 3 presents the results with the centred variables. As predicted by hypothesis H1, no direct effect of the cultural dimensions on entrepreneurial intention was found. Besides, since the coefficients for the TPB antecedents remain roughly the same as in model 2, no evidence of interaction effect between cultural dimensions and intention antecedents is found. Regarding GDP per capita, a marginal negative effect is found, meaning that people in higher-income regions tend to present slightly lower entrepreneurial intentions than those in lower-income regions.

Finally, in Model 4, only demographics, culture and income have been considered. As may be seen, there is a significant influence of the embeddedness/autonomy dimension on entrepreneurial intention, and the effect of income is more negative and highly significant. But when TPB antecedents are included (Model 3) this relationship disappears. This would confirm that culture affects intention indirectly, only through its influence on its antecedents (as Hypothesis H1 stated).

To test hypothesis H2, new linear regression models were run, with the TPB antecedents as dependent variables (see Table 4). Models A1 (explaining attitude to entrepreneurship), S1 (explaining subjective norm) and P1 (explaining perceived behavioural control) include only demographic variables. Again, age and age-squared had to be eliminated from the analysis due to multicollinearity problems. In this case, though, the trouble with regard to the socioeconomic level was much weaker and this variable could be kept.

In all three cases, the explained variance is much lower than in the case of intention. Still, a family role model and a relatively high socioeconomic level, both exert a positive and significant effect over the three antecedents. Experience, either as employee or self-employed, also helps increase perceived behavioural control. In turn, with regard to attitude towards entrepreneurship, only self-employment experience is significant. Finally, males feel themselves as more able to become entrepreneurs than females.

Model A2 includes cultural and income variables to explain the attitude towards entrepreneurship. As may be seen, people in regions where autonomy is relatively prioritized tend to present a more positive attitude. In contrast, but in line with results in Table 3, people in relatively richer regions have a less positive attitude towards entrepreneurship. In Model S2, again, cultural variables at the regional level do exert a significant influence on the individuals' subjective norm. Finally, in Model P2, both cultural variables (embeddedness/autonomy and mastery/harmony dimensions are positively related) and income (negatively related) contribute to explaining the individuals' level of perceived behavioural control. Therefore, it may be concluded that hypothesis $\mathrm{H} 2$ is, at least, partly supported. In particular, the hierarchy/egalitarianism 
cultural dimension has not shown any relation to the antecedents of entrepreneurial intentions.

Table 4: Linear regression models on intention antecedents

\begin{tabular}{|c|c|c|c|c|c|c|}
\hline \multirow[b]{3}{*}{ Explanatory Variables } & \multicolumn{6}{|c|}{ Dependent Variables } \\
\hline & \multicolumn{2}{|c|}{$\begin{array}{c}\text { Attitude to } \\
\text { entrepreneurship }\end{array}$} & \multicolumn{2}{|c|}{ Subjective norm } & \multicolumn{2}{|c|}{$\begin{array}{c}\text { Perceived Behavioural } \\
\text { Control }\end{array}$} \\
\hline & $\begin{array}{c}\text { Model A1 } \\
\beta\end{array}$ & $\begin{array}{c}\text { Model A2 } \\
\beta\end{array}$ & $\begin{array}{c}\text { Model S1 } \\
\qquad \beta\end{array}$ & $\begin{array}{c}\text { Model S2 } \\
\qquad \beta\end{array}$ & $\begin{array}{c}\text { Model P1 } \\
\beta\end{array}$ & $\begin{array}{c}\text { Model P2 } \\
\beta\end{array}$ \\
\hline Gender & $.034 \dagger$ & $.036^{*}$ & -.027 & -.025 & $.120 * * *$ & $.123^{* * *}$ \\
\hline Labour Experience & .012 & .007 & .017 & .014 & $.051^{* *}$ & $.045^{*}$ \\
\hline Self-Employment Exp. & $.108^{* * *}$ & $.101^{* * *}$ & .029 & .028 & $.107^{* * *}$ & $.102^{* * *}$ \\
\hline Family Role Model & $.062 * *$ & $.060 * *$ & $.093 * * *$ & $.091^{* * *}$ & $.056^{* *}$ & $.058 * *$ \\
\hline Socioeconomic level & $.044^{*}$ & $.047 *$ & $.045^{*}$ & $.048 * *$ & $.087 * * *$ & $.088 * * *$ \\
\hline Embedd/Auton (centred) & --- & $.142 * * *$ & --- & $.088^{* *}$ & --- & $.095 * *$ \\
\hline Hierar/Egalitar (centred) & --- & $.050 \dagger$ & --- & -.030 & --- & .024 \\
\hline Mast/Harmo (centred) & --- & $.141^{* *}$ & --- & $.110^{* *}$ & --- & $.119 * *$ \\
\hline GDP per capita (centred) & --- & $-.151 * * *$ & --- & $-.064 *$ & --- & $-.086^{* *}$ \\
\hline $\begin{array}{r}R^{2} \\
\text { Adjusted } R^{2} \\
\Delta R^{2}\end{array}$ & $\begin{array}{c}.020 \\
.018 \\
.020 * * *\end{array}$ & $\begin{array}{c}.033 \\
.030 \\
.013^{* * *}\end{array}$ & $\begin{array}{c}.013 \\
.011 \\
.013^{* * *}\end{array}$ & $\begin{array}{l}.016 \\
.013 \\
.003^{*}\end{array}$ & $\begin{array}{c}.042 \\
.041 \\
.042^{* * *}\end{array}$ & $\begin{array}{c}.048 \\
.045 \\
.005^{* *}\end{array}$ \\
\hline
\end{tabular}

$\dagger p<0.1, * p<0.05, * * p<0.01, * * * p<0.001$.

\section{Discussion}

Results of the empirical study have been considerably satisfactory, since the two hypotheses formulated were supported. From them, it may be claimed that cultural values of a region do affect the level of entrepreneurial intention of its inhabitants. This effect is, however, only indirect, through the TPB antecedents of intention.

A number of contributions had already stressed the influence of culture on entrepreneurship (Davidsson, 1995; Davidsson \& Wiklund, 1997; Frederking, 2004). Nevertheless, the mechanism through which this effect is exerted is far from clear. Firstly, it has been argued that a supportive culture would lead to social legitimation, making the entrepreneurial career more valued and socially recognized in that culture, thus creating a favourable institutional environment. Thus, more people will try to start their ventures, irrespective of their personal beliefs and attitudes (Etzioni, 1987). Secondly, it may be that a culture sharing more pro-entrepreneurial values and patterns of thinking would lead to more individuals showing psychological traits and attitudes consistent with entrepreneurship (Krueger, 2000, 2003). Thus, more people will try to become entrepreneurs. 
Results from this paper would imply support for the psychological traits approach, since the people from regions prioritizing autonomy over embeddedness do present more positive attitude towards entrepreneurship, subjective norm and perceived behavioural control (PBC). And this, in turn, would derive in higher entrepreneurial intention. The same could be said about regions stressing harmony over mastery, at least with regard to subjective norm and PBC. This would be in line with some previous evidence suggesting that a high perceived valuation of entrepreneurship in a society leads to more positive attitudes and intentions by individuals (Krueger \& Carsrud, 1993; Liñán, Urbano \& Guerrero, 2011).

However, this should not be taken to imply that the social legitimation approach may be disregarded. As indicated by Schwartz (1992), the influence of culture on individuals' behaviour also works through social institutions and their actions (through legislation, government directives, the education system, etc.), selecting and prioritizing some values over the others. In this sense, people tend to carry out what they believe is socially appropriate behaviour, even if they do not share the underlying values (Bourdieu, 1991; Markus \& Kitayama, 1991; Schwartz, 1994).

Alternatively, it has also been argued that it is "misfit" individuals who attempt to start a venture. That is, irrespective of the specific cultural characteristics of a country, people not sharing dominant cultural values -dissatisfied individuals- will attempt the entrepreneurial path (Hofstede et al. 2004). The present study does not allow confirming or rejecting this assumption. It would be necessary to compare each person's values with the regional culture. This is, precisely, one of the future lines of research that we will try to undertake within the VIE project.

Regarding the effect of income, the negative relationship found may be, at first sight, difficult to interpret. There is considerable evidence of the existence of a U-shaped relation between development and entrepreneurship (Bosma \& Levie, 2010; Carree, et al., 2002; Pinillos \& Reyes, 2011). According to the income level, Spain should be placed on the upper right-hand side of the curve. However, within the regions, the effect of income is negative.

One possible explanation would be that within an economy (with a common market and institutional framework), a new U-shape relationship would be found, distinguishing between less-developed and more-developed areas of the country. Or it may simply be that data collection was carried out during recession and less-developed regions exhibit higher unemployment. In this sense, a stronger push factor and a lower opportunity cost would make more people in these lower-income regions intend to become entrepreneurs.

The empirical analysis tends to support our hypotheses. However, explained variance (R-squared) is very low. Therefore, the effect of culture could be considered as weak, despite considerable regional differences in this respect. At least, this would be the case within Spain which, despite its cultural diversity, shares common institutional frameworks and markets. Additionally, some authors argue that cultural norms are more closely related to normatively-regulated behaviours, while individual values relate to behaviours for which there are no clearly established norms (Fischer, 2004, 2006). In this sense, there would be no strong normative regulations about starting a venture in Spain, which may explain the relatively weak effect of culture. 


\section{Conclusions}

Overall, it has been shown that the culture of a society does play a role in determining the entrepreneurial intention of the people sharing it. The effect is indirect, though. The real influence of shared values is shown when individuals establish their personal attitude towards starting a venture, their subjective norm and their perceived control (or self-efficacy). Besides, culture changes very slowly (Hofstede, 1980; Schwartz, 2004). As a consequence, it may not be easily manipulated to "create" entrepreneurs in the short run.

However, it does not mean that any intervention to promote entrepreneurship is useless. The diffusion of autonomy and, to some degree, harmony values could be especially helpful in making individuals more prone to the entrepreneurial activity. In particular, recent trends seem to be emphasizing the importance of self-direction and curiosity (intellectual autonomy) in many different job situations. At the same time, the end of the job-for-life is highlighting the importance of self-realization and enjoyment when deciding a professional career path (affective autonomy). Finally, growing ecological concern (harmony) has led to development of a whole new industry and become a huge source of business opportunities. It seems that these values are becoming more and more useful in modern economies, and not just to help promote entrepreneurship.

The present study may suffer from a number of limitations. In particular, only seven regions were analysed. This caused a number of statistical problems (heteroscedasticity) that had to be solved by a zero-mean transformation. The generalizability of these findings is, therefore, not established. Future research should try to replicate these results on a wider set of regions, in different countries, and even in cross-country studies. A second limitation is related to the mechanism through which culture influences attitudes and behaviour. Although results seem to support the psychological traits approach, much research is needed to advance knowledge in this field. Therefore, it is a line of research that the authors plan to pursue in the near future, within the development of the VIE project.

\section{References}

Ajzen, I. (1991). The Theory of Planned Behavior. Organizational Behavior and Human Decision Processes, 50(2), 179-211.

Ajzen, I. (2001). Nature and operation of attitudes. Annual Review of Psychology, 52, 27-58.

Ajzen, I. (2002a). Constructing a TPB questionnaire: conceptual and methodological considerations Retrieved August 2011, from http://www.people.umass.edu/aizen/

Ajzen, I. (2002b). Perceived behavioral control, self-efficacy, locus of control, and the theory of planned behavior. Journal of Applied Social Psychology, 32(4), 665-683.

Ajzen, I. (2005). Attitudes, Personality and Behavior. Maidenhead: Open University Press.

Ajzen, I., \& Fishbein, M. (1980). Understanding attitudes and predicting social behavior. Englewood Cliffs, NJ: Prentice-Hall. 
Alexei, T., \& Kolvereid, L. (1999). Self-employment intentions among Russian students. Entrepreneurship and Regional Development, 11(3), 269-271.

Audet, J. (2004). A Longitudinal Study of the Entrepreneurial Intentions of University Students. Academy of Entrepreneurship Journal, 10 (1 et 2), 3-16.

Autio, E., Keeley, R. H., Klofsten, M., Parker, G. G. C., \& Hay, M. (2001). Entrepreneurial Intent among Students in Scandinavia and in the USA. Enterprise and Innovation Management Studies, 2(2), 145-160.

Bandura, A. (1982). Self- Efficacy Mechanism in Human Agency. American Psychologist, 37, $122-147$.

Bandura, A. (1997). Self-efficacy: The exercise of control. New York: Freeman.

Baron, R. A. (1998). Cognitive mechanisms in entrepreneurship: why and when entrepreneurs think differently than other people. Journal of Business Venturing, 13, 275-294.

Baron, R. A. (2004). The cognitive perspective: a valuable tool for answering entrepreneurship's basic "why" questions. Journal of Business Venturing, 19(2), 221-239.

Baum, J. R., Frese, M., \& Baron, R. A. (2007). The Psychology of Entrepreneurship. New Jersey: Lawrence Erlbaum.

Bird, B. (1988). Implementing entrepreneurial ideas: the case for intention. Academy of Management Review, 13, 442-453.

Bosma, N., \& Levie, J. (2010). Global Entrepreneurship Monitor: 2009 Executive Report. Retrieved from http://www.gemconsortium.org/

Bourdieu, P. (1991). Language and Symbolic Power. Cambridge: Polity Press.

Busenitz, L. W., \& Lau, C. M. (1996). A cross-cultural cognitive model of new venture creation. Entrepreneurship Theory and Practice, 20(4), 25-39.

Carree, M. A., van Stel, A., Thurik, A. R., \& Wennekers, A. R. M. (2002). Economic development and business ownership: an analysis using data of 23 OECD countries in the period 1976-1996. Small Business Economics, 19(3), 271-290.

Cooper, A. C., Gimeno, J., \& Woo, C. Y. (1994). Initial Human and Financial Capital as Predictors of New Venture Performance. Journal of Business Venturing, 9(5), 371-395.

Dahlqvist, J., Davidsson, P., \& Wiklund, J. (2000). Initial conditions as predictors of new venture performance: A replication and extension of the Cooper et al. Study. Enterprise and Innovation Management Studies, 1(1), 1-17.

Davidsson, P. (1995). Culture, structure and regional levels of entrepreneurship. Entrepreneurship and Regional Development, 7(1), 41-62.

Davidsson, P., \& Wiklund, J. (1997). Values, beliefs and regional variations in new firm formation rates. Journal of Economic Psychology, 18(2-3), 179-199.

Douglas, E. J., \& Shepherd, D. A. (2000). Entrepreneurship as Utility-Maximizing Response. Journal of Business Venturing, 15(3), 231-251.

Etzioni, A. (1987). Entrepreneurship, adaptation and legitimation: a macro-behavioral perspective. Journal of Economic Behavior \& Organization, 8, 175-189.

European Commission. (2003). Green Paper - Entrepreneurship in Europe. Brussels: DG Enterprise. European Commission.

Feather, N. T. (1995). Values, valences. and choice: The influence of values on the perceived attractiveness and choice of alternatives. Journal of Personality and Social Psychology, $68,1135-1151$.

Fischer, R. (2004). Standardization to account for Cross Cultural Response Bias: a

classification of score adjustment procedures and review of research in JCCP. Journal of

Cross-Cultural Psychology, 35,3, 263-282.

Fischer, R. (2006). Congruence and Functions of Persoanl and Cultural Values: Do My

Values Reflect My Culrure's Values? Personal and Social Psychology Bulletin, 32(11), 14191431.

Frederking, L. C. (2004). A cross-national study of culture, organization and entrepreneurship in three neighbourhoods. Entrepreneurship and Regional Development, 16(3), 197-215.

Gollwitzer, P. M. (1996). The volitional benefits of planning. In P. M. Gollwitzer \& J. A. Bargh (Eds.), The psychology of action. New York: Guildford. 
Hofstede, G. (1980). Culture's consequences: international differences in work-related values. Beverly Hills: Sage Publications.

Hofstede, G. (1991). Cultures and organizations: software of the mind. London: McGraw-Hill.

Hofstede, G. (2003). Culture's consequences: comparing values, behaviors, institutions and organizations across nations (2nd edition ed.). Newbury Park: Sage Publications.

Hofstede, G., Noorderhaven, N., Thurik, A. R., Uhlaner, L. M., Wennekers, A. R. M., \& Wildeman, R. E. (2004). Culture's role in entrepreneurship: self-employment out of dissatisfaction. In T. E. Brown \& J. M. Ulijn (Eds.), Innovation, entrepreneurship and culture (pp. 162-203). Cheltenham: Edward Elgar.

Inglehart, R. (1990). Culture shift in advanced industrial society. Princeton: University

Press.

Inglehart, R. (1997). Modernization and Postmodernization. Princeton: Princeton University Press.

Inglehart, R., \& Baker, W. E. (2000). Modernisation, cultural change, and the persistence of traditional values. American Sociological Review, 65(1), 19-51.

Kagitcibasi, C. (1997). Individualism and collectivism. In J. W. Berry, M. H. Segall \& C. Kagitcibasi (Eds.), Handbook of cross-cultural psychology (2nd ed., Vol. 3, pp. 1-50). Boston: Allyn \& Bacon.

Kahl, J. A. (1968). The measurement of modernism: A study of values in Brazil and Mexico. Austin: University of Texas Press.

Kets de Vries, M. F. R. (1977). The entrepreneurial personality: A person at the crossroad. The Journal of Management Studies, 14, 34-58.

Kolvereid, L. (1996). Prediction of employment status choice intentions. Entrepreneurship Theory and Practice, 21(1), 47-57.

Krueger, N. F. (2000). The cognitive infrastructure of opportunity emergence. Entrepreneurship Theory and Practice, 24(3), 5-23.

Krueger, N. F. (2003). The cognitive psychology of entrepreneurship. In Z. J. Acs \& D. B. Audretsch (Eds.), Handbook of entrepreneurship research: An interdisciplinary survey and introduction (pp. 105-140). London: Kluwer.

Krueger, N. F., \& Carsrud, A. L. (1993). Entrepreneurial intentions: applying the theory of planned behavior. Entrepreneurship and Regional Development, 5(4), 315-330.

Krueger, N. F., Reilly, M. D., \& Carsrud, A. L. (2000). Competing models of entrepreneurial intentions. Journal of Business Venturing, 15(5-6), 411-432.

Langowitz, N., \& Minniti, M. (2007). The entrepreneurial propensity of women. [Article]. Entrepreneurship Theory and Practice, 31(3), 341-364.

Lee, S. M., \& Peterson, S. J. (2000). Culture, entrepreneurial orientation, and global competitiveness. Journal of World Business, 35(4), 401-416.

Levesque, M., \& Minniti, M. (2006). The effect of aging on entrepreneurial behavior. Journal of Business Venturing, 21(2), 177-194.

Li, W. (2006). Entrepreneurial intentions among international students: testing a model of entrepreneurial intention.

Liñán, F., \& Chen, Y. W. (2009). Development and cross-cultural application of a specific instrument to measure entrepreneurial intentions. Entrepreneurship Theory and Practice, 33(3), 593-617.

Liñán, F., Urbano, D., \& Guerrero, M. (2011). Regional variations in entrepreneurial cognitions: Start-up intentions of university students in Spain. Entrepreneurship and Regional Development, 23(3\&4), 187-215. doi: 10.1080/0898562090323392

Markus, H. R., \& Kitayama, S. (1991). Culture and the self: Implications for cognition, emotion and motivation. Psychological Review, 98, 224-253.

Matthews, C. H., \& Moser, S. B. (1996). A longitudinal investigation of the impact of family background and gender on interest in small firm ownership. Journal of Small Business Management, 34(2), 29-43.

McClelland, D. C. (1961). The achieving society. Princeton: Van Nostrand. 
Minniti, M., Bygrave, W. D., \& Autio, E. (2006). GEM, Global Entrepreneurship Monitor, 2005 Executive Report. : London, U.K. \& Babson Park, MA: London Business School \& Babson College.

Minniti, M., \& Nardone, C. (2007). Being in someone else's shoes: the role of gender in nascent entrepreneurship. [Article]. Small Business Economics, 28(2-3), 223-238.

Moriano, J. A., Palací, F. J., \& Morales, J. F. (2007). The Psychosocial Profile of the University Entrepreneur. Psychology in Spain, 11, 72-84.

Neck, C. P., Neck, H. M., Manz, C. C., \& Godwin, J. (1999). 'I think I can; I think I can': A selfleadership perspective toward enhancing entrepreneur thought patterns, self-efficacy, and performance. Journal of Managerial Psychology, 14(5), 477-501.

OECD. (1998). Fostering entrepreneurship. Paris: Organisation for Economic Co-operation and Development.

Pihie, Z. A. L. (2009). Entrepreneurship as a Career Choice: An Analysis of Entrepreneurial Self-Efficacy and Intention of University Students. European Journal of Social Sciences, 9(2), 338-349.

Pinillos, M.-J., \& Reyes, L. (2011). Relationship between individualist-collectivist culture and entrepreneurial activity: evidence from Global Entrepreneurship Monitor data. Small Business Economics, 37(1), 23-37. doi: 10.1007/s11187-009-9230-6

Rauch, A., \& Frese, M. (2007). Let's put the person back into entrepreneurship research: A meta-analysis on the relationship between business owners' personality traits, business creation, and success. European Journal of Work and Organizational Psychology, 16(4), 353-385.

Reynolds, P. D., Storey, D. J., \& Westhead, P. (1994). Cross-national comparison of the variation in new firm rates. Regional Studies, 28(4), 443-456.

Robinson, P. B., Stimpson, D. V., Huefner, J., \& Hunt, H. K. (1991). An attitude approach to the prediction of entrepreneurship. Entrepreneurship Theory and Practice, 15(4), 13-31.

Rokeach, M. (1973). The nature of human values. Nueva York: Free Press.

Scherer, R. F., Brodzinsky, J. D., \& Wiebe, F. A. (1991). Examining the relationship between personality and entrepreneurial career preference. Entrepreneurship and Regional Development, 3, 195-206.

Schwartz, S. H. (1992). Universals in the content and structure of values: Theoretical advances and empirical tests in 20 countries. In M. P. Zanna (Ed.), Advances in Experimental Social Pychology (Vol. 25, pp. 1-65). Nueva York: Academic Press.

Schwartz, S. H. (1994). Beyond Individualism-Collectivism: New cultural dimensions of values. In U. Kim, H. C. Triandis, C. Kagitçibasi, S. C. Choi \& G. Yoon (Eds.), Individualism and collectivism. Theory, method, and applications (pp. 85-119). Thousand Oaks, CA: Sage.

Schwartz, S. H. (1999). Cultural value differences: some implications for work. Applied Psychology: An International Review, 48, 23-48.

Schwartz, S. H. (2004). Mapping and Interpreting Cultural Differences around the World. In H. Vinken, J. Soeters \& P. Ester (Eds.), Comparing Cultures, Dimensions of Culture in a Comparative Perspective. Leiden, The Netherlands: Brill.

Schwartz, S. H. (2006). Les valeurs de base de la personne : théorie, mesures et applications. [Basic Human Values: Theory, methods and applications]. Revue Francaise De Sociologie, 47(4), 929-968.

Schwartz, S. H. (2007). Value orientations. measurement, antecedents and consequences across nations. In R. Jowell, C. Roberts, R. Fitzgerald \& G. Eva (Eds.), Measuring attitudes cross-nationally (pp. 169-203). London: Sage.

Schwartz, S. H., \& Bilsky, W. (1987). Toward a universal psychological structure of human values. Journal of Personality and Social Social Psychology, 53, 550-562.

Schwartz, S. H., \& Bilsky, W. (1990). Toward a theory of the universal content and structure of values: Extensions and cross-cultural replications. Journal of Personality and Social Psychology, 58, 878-891.

Schwartz, S. H., \& Ros, M. (1995). Values in the West: A theoretical and empirical challenge to the Individualism-Collectivism cultural dimension. World Psychology, 1, 99-122. 
Shapero, A. (1982). Social Dimensions of Entrepreneurship. In C. A. Kent, D. L. Sexton \& K. Vesper (Eds.), The Encyclopedia of Entrepreneurship (pp. 72-90). Englewood Cliffs: Prentice Hall.

Storey, D. J. (1994). Understanding the small business sector. London: Routledge.

Tkachev, A., \& Kolvereid, L. (1999). Self-employment intentions among Russian students. Entrepreneurship and Regional Development, 11(3), 269-280.

Triandis, H. C. (1995). Individualism \& collectivism. Boulder, Colo ; Oxford: Westview.

van Gelderen, M., Brand, M., van Praag, M., Bodewes, W., Poutsma, E., \& van Gils, A. (2006). Explaning Entrepreneurial Intentions by Means of the Theory of Planned Behavior. Research Working Papers Series, 2, 1-33.

van Gelderen, M., Brand, M., van Praag, M., Bodewes, W., Poutsma, E., \& van Gils, A. (2008). Explaining entrepreneurial intentions by means of the theory of planned behaviour. Career Development International, 13, 538-559. doi: 10.1108/13620430810901688

Van Stel, A., Wennekers, A. R. M., Thurik, A. R., \& Reynolds, P. (2003). Explaining nascent entrepreneurship across countries. SCALES-paper N2003-01. Zoetermeer: EIM Business and Policy Research.

Venkatraman, N. (1989). The concept of fit in strategy research: toward verbal and statistical correspondence. Academy of Management Review, 14(3), 423-444.

Verheul, I., Wennekers, A. R. M., Audretsch, D. B., \& Thurik, A. R. (2002). An eclectic theory of entrepreneurship. In D. B. Audretsch, A. R. Thurik, I. Verheul \& A. R. M. Wennekers (Eds.), Entrepreneurship: Determinants and Policy in a European-US Comparison. Boston/ Dordrecht: Kluwer Academic Publishers.

Verplanken, B., \& Holland, R. W. (2002). Motivated decision making: Effects of activation and self-centrality of values on choices and behavior. Journal of Personality and Social Psychology, 82, 434-447.

Williams, R. M. (1968). Values. In E. Sills (Ed.), International encyclopedia of the social sciences. New York: MacMillan. 